\title{
1 Zinc isotope fractionation as an indicator of geochemical attenuation processes
}

2 Harish Veeramani ${ }^{1+*}$, Jane Eagling ${ }^{1}$, Julia H. Jamieson-Hanes ${ }^{1}$, Lingyi Kong ${ }^{1}$, Carol J. Ptacek ${ }^{1}$ and David W.

3 Blowes $^{1}$

$4 \quad{ }^{1}$ Department of Earth and Environmental Sciences

5 University of Waterloo

6200 University Avenue West

7 Waterloo, Ontario

8 Canada N2L $3 G 1$

9 *harish.veeramani@uwaterloo.ca

10 †Present Address:

11 School of Engineering

12 University of Glasgow

13 Glasgow G12 8QQ

14 United Kingdom

15 Phone: $+44(0) 141-330-1839$

16 Email: harish.veeramani@glasgow.ac.uk

\section{Abstract}

18 Isotope ratio measurements have been used to trace environmental processes, especially in subsurface

19 environments. In this study we evaluated the potential to use Zinc (Zn) stable isotope ratios as indicators

20 of attenuation processes including sorption and precipitation. Zn isotope fractionation was observed 
21 during distinctly different precipitation processes. Isotope measurements confirmed an increasing trend

22 in aqueous $\delta^{66} \mathrm{Zn}$ in solution during sphalerite $(\mathrm{ZnS})$ formation, but a decreasing trend in $\delta^{66} \mathrm{Zn}$ during the

23 precipitation of hydrozincite $\left(\mathrm{Zn}_{5}\left(\mathrm{CO}_{3}\right)_{2}(\mathrm{OH})_{6}\right)$ and hopeite $\left(\mathrm{Zn}_{3}\left(\mathrm{PO}_{4}\right)_{2} \cdot 4 \mathrm{H}_{2} \mathrm{O}\right)$. In contrast, time-dependent

24 sorption of $\mathrm{Zn}$ onto ferrihydrite at a fixed $\mathrm{pH}$ did not cause isotopic fractionation in the solution over the

25 duration of the experiments. These findings suggest potential applications of stable isotope

26 measurements in aqueous environments for determining reaction pathways (e.g.: precipitation with

27 common groundwater constituents) leading to $\mathrm{Zn}$ attenuation.

28

29

30

31

32

33

34

35

36

37

38

39 


\section{Introduction}

41 Zinc $(\mathrm{Zn})$ is a first row transition chalcophile metal (d-block) that is ubiquitous in the environment and

42 participates in a diversity of biogeochemical processes in soil, sediments and aquatic settings. ${ }^{1,2}$ It is an

43 essential micronutrient at low concentrations ${ }^{3}$ and toxic at higher concentrations. ${ }^{4}$ Although sorption of

$44 \mathrm{Zn}$ is often assumed to be the primary process governing its fate and transport, ${ }^{5,6}$ it can precipitate as

45 sphalerite $(\mathrm{ZnS})$, $\mathrm{Zn}$ hydroxide $\left(\mathrm{Zn}(\mathrm{OH})_{2}\right)$, $\mathrm{Zn}$ carbonate $\left(\mathrm{ZnCO}_{3}\right)$, or hydrozincite $\left(\mathrm{Zn}_{5}(\mathrm{OH})_{6}\left(\mathrm{CO}_{3}\right)_{2}\right)$ that

46 control its concentrations in the environment. ${ }^{6,7,8,9,10}$

47 Zinc has a high ionization potential making precise determination of the isotope ratios challenging with

48 conventional thermal ionization mass spectrometry. Advances in high-precision analytical

49 instrumentation such as the multicollector inductively-coupled plasma mass spectrometer ${ }^{11}$ (MC-ICP-

50 MS) have enabled the study of non-traditional stable isotope fractionation associated with

51 biogeochemical processes occurring in the environment. Zinc isotopic fractionation has been shown to

52 occur during sorption, ${ }^{12,13,14}$ chemical diffusion, ${ }^{15}$ and biological incorporation. ${ }^{16}$ Isotope fractionation

53 has been reported to range from $0.5-1 \%$ in oceanic sediments, ${ }^{17}$ and soils and plants. ${ }^{18}$ Zinc isotope

54 ratios have been used as indicators of biogeochemical processes, ${ }^{19,} 20$ anthropogenic contamination in

55 river water samples, ${ }^{20}$ watersheds, $^{21}$ wetlands, $^{22}$ ore deposits, ${ }^{23}$ waste-rock drainage, ${ }^{24}$ marine

56 sediments, ${ }^{17}$ seawater, ${ }^{25}$ and biological materials. ${ }^{26}$ Variations in isotopic abundances of transition

57 metals such as $\mathrm{Zn}$ in biological and geochemical materials have stirred considerable interest into identifying the underlying mechanisms governing isotope fractionation processes in nature.

The present study reports $\mathrm{Zn}$ isotope fractionation associated with attenuation processes that

61 ratios in aquatic settings and in anticipating changes in water quality. 


\section{Materials and Methods}

64 The reagents used in the experiments were of ultrapure analytical grade. All labware was acid-washed

65 by soaking in $10 \% \mathrm{HNO}_{3}$ overnight and rinsed five times in high-resistivity $(18.2 \mathrm{M} \Omega \cdot \mathrm{cm})$ water prior to

66 the experiments.

\section{$67 \quad 2.1$ Sorption Experiments}

68

\subsubsection{Iron Oxide Synthesis}

69 A batch of 2-line ferrihydrite was synthesized according to the method described by Antelo and 70 coworkers. ${ }^{27}$ Details of the synthesis are included in the Supporting Information (SI). Samples of

71 ferrihydrite were periodically checked by X-ray diffraction (XRD) to ensure the absence of goethite 72 (Figure S1).

\section{$73 \quad$ 2.1.2 Time-dependent sorption experiment}

74 The sorption experiment was carried out in a $1.9 \mathrm{~L}$ batch reactor containing $2 \mathrm{~g} / \mathrm{L}$ of freshly synthesized

75 ferrihydrite. The mineral was suspended in $1.9 \mathrm{~L}$ of $0.1 \mathrm{M} \mathrm{KNO}_{3}$ that was made using high-resistivity

$76(18.2 \mathrm{M} \Omega \cdot \mathrm{cm})$ water. The suspension was equilibrated for 24 hours and stirred continuously while being

77 purged with ultrapure $\mathrm{Ar}$ gas to minimize $\mathrm{CO}_{2}$ intrusion over the course of the experiment. An auto-

78 titrator (Metrohm) was used in the $\mathrm{pH}$ stat mode to maintain the $\mathrm{pH}$ at 7.2 using $0.05 \mathrm{M} \mathrm{NaOH}$ and 0.01

$79 \mathrm{M} \mathrm{HCl}$. Geochemical modeling using the PHREEQC ${ }^{28}$ with the WATEQ4 database ${ }^{29}$ indicated the solution

80 was undersaturated with respect to $\mathrm{Zn}(\mathrm{OH})_{2}$ at $\mathrm{pH}$ values $<7.5$ under the experimental conditions. The

81 sorption experiment was initiated by adding an acidic stock solution of $\mathrm{ZnCl}_{2}$ (c.a. $75 \mu \mathrm{M}$ ) to a suspension

82 of ferrihydrite. Samples were withdrawn at specified intervals, centrifuged, filtered using disposable 0.2

$83 \mu \mathrm{m}$ Polysulfone (PES) filters (VWR 28145-499) and acidified with $\mathrm{HNO}_{3}$ for cation analysis by inductively- 
85 ratio determinations.

\subsection{Precipitation Experiments and Characterization}

87 The precipitation of selected $\mathrm{Zn}$ phases was carried out in a series of batch experiments by adding 88 varying concentrations of counter-anions to acidic and anoxic solutions of $\mathrm{ZnSO}_{4}$ or $\mathrm{ZnCl}_{2}$. The 89 suspensions were allowed to equilibrate for 24 hours inside an anoxic glove box followed by 90 centrifugation and filtration. The filtrate was acidified using ultrapure nitric acid for isotope analysis.

91 Parallel time-dependent precipitation tests were carried out to determine the time to equilibrium.

92 Further details of the precipitation experiments including sample preparation and solid-phase 93 characterization are included in the SI.

\subsection{Isotope Analysis}

Aqueous samples were prepared for $\mathrm{Zn}$ isotopic analysis in a clean laboratory environment and under a HEPA-filtered laminar fume hood following a modified procedure described by Marechal et al. ${ }^{30} \mathrm{~A}$

97 detailed description of the sample preparation and the MC-ICP-MS parameters are included in the SI. and ${ }^{72} \mathrm{Ge}$ to correct for isobaric interferences. Instrumental mass bias was corrected using a double-spike technique and the application of a double-nested iterative routine; isotope ratios are reported as $\delta^{66} \mathrm{Zn}$ relative to the international $\mathrm{Zn}$ isotope standard IRMM 3702, where:

$$
\delta^{66} \mathrm{Zn}=\left[\frac{\left({ }^{66} \mathrm{Zn} /{ }^{64} \mathrm{Zn}\right)_{\text {sample }}}{\left({ }^{66} \mathrm{Zn} /{ }^{64} \mathrm{Zn}\right)_{\text {IRMM } 3702}}-1\right] \times 1000 \%
$$

103 Results were normalized to daily measurements of the IRMM 3702 standard. The uncertainty of the 104 isotope measurements was determined to be $\pm 0.06 \%$ based on twice root-mean-square difference for 
10519 pairs of duplicate sample preparations. The $\delta^{66} \mathrm{Zn}$ values of the starting solutions of $\mathrm{ZnCl}_{2}$ and $\mathrm{ZnSO}_{4}$ 106 were found to be $-0.14 \pm 0.03$ and $-0.21 \pm 0.04 \%$, respectively. The fractionation factors were derived 107 from the experimental results by fitting to Rayleigh distillation models. The magnitude of the isotopic 108 fractionation is measured by the fractionation factor, $\alpha$ :

$$
\alpha=R_{\text {product }} / R_{\text {reactant }}(2)
$$

110 where $\mathrm{R}$ is the isotope ratio.

111 For convenience, the fractionation factors can be expressed in terms of $\varepsilon$, a similar per mil quantity:

$$
\varepsilon=(\alpha-1) \times 1000 \%
$$

113

114 


\section{RESULTS AND DISCUSSION}

\subsection{Zn Sorption and Isotope Fractionation}

117 Aqueous $\mathrm{Zn}(\mathrm{II})$ was removed from solution over the course of 24 hours at $\mathrm{pH} 7.2$ (Figure S2). This 118 observation is consistent with previous findings that report $\mathrm{Zn}$ removal from solution in this $\mathrm{pH}$ range.

$119{ }^{13,14}$ Drifts in $\mathrm{pH}$ during the experiment were controlled with an auto-titrator. The sorption of $\mathrm{Zn}$ onto 120 ferrihydrite at a $\mathrm{pH}$ below the point of zero charge $(\mathrm{PZC}=7.96-8.0)$ of ferrihydrite ${ }^{31,32}$ is likely due to the 121 formation of inner sphere sorption complexes. ${ }^{33,34}$

The $\delta^{66} \mathrm{Zn}$ value of the starting/unreacted solution of $\mathrm{ZnCl}_{2}$ was $-0.14 \pm 0.03 \%$ relative to the

123 IRMM-3702 standard. The data in Figure 1 has been recalculated relative to the isotopic composition of 124 the starting solution $(-0.14 \pm 0.03 \%$ o). The uptake of $\mathrm{Zn}$ onto ferrihydrite at a fixed $\mathrm{pH}$ did not seem to 125 alter the isotopic ratios as a function of time as indicated by the $\delta^{66} \mathrm{Zn}$ values of the residual $\mathrm{Zn}$ in 126 solution, which varied between 0.01 and $-0.05 \%$ relative to the input solution (Figure 1 ). This finding 127 differs from an earlier study that reported a depletion of $\delta^{66} \mathrm{Zn}$ in solution (-0.02 to $-0.59 \%$ relative to 128 the IRMM-3702 standard) during $\mathrm{Zn}(\mathrm{II})$ sorption onto ferrihydrite where isotopic equilibrium was 129 reached after $16 \mathrm{~h}$ of exposure. ${ }^{14} \mathrm{In}$ our experiments the aqueous concentration of $\mathrm{Zn}$ was observed to 130 decrease continuously over time (Figure S2), suggesting that equilibrium was not attained in this study.

131 This may be due to differences in experimental conditions including a higher solid to liquid ratio ( $2 \mathrm{~g} / \mathrm{L}$ vs $1321 \mathrm{~g} / \mathrm{L})$, lower initial $\mathrm{Zn}$ concentration $(0.08 \mathrm{mM}$ vs $1 \mathrm{mM})$ and different $\mathrm{Zn}$ salt $\left(\mathrm{ZnCl}_{2}\right.$ vs $\left.\mathrm{Zn}\left(\mathrm{NO}_{3}\right)_{2}\right)$. 133 Consequently the lack of isotopic changes $(\delta 66 \mathrm{Zn})$ observed here could be attributed to kinetic effects. 134 Isotope fractionation associated with sorption has been recognized for several metals, but is highly 135 element specific. ${ }^{35}$

136 A study investigating $\mathrm{pH}$-dependent sorption of $\mathrm{Zn}$ onto pyrolusite, birnessite, and corundum reported 137 decreasing $\delta^{66} \mathrm{Zn}$ values for residual $\mathrm{Zn}$ in solutions with increasing $\mathrm{pH}$ values and increasing $\delta^{66} \mathrm{Zn}$ values 
during $\mathrm{Zn}$ sorption onto goethite. ${ }^{13}$ However similar $\mathrm{pH}$-dependent studies have also reported 139 decreasing $\delta^{66} \mathrm{Zn}$ values in solution during $\mathrm{Zn}$ sorption onto ferrihydrite and goethite. ${ }^{14}$

Studies examining sorption of $\mathrm{Zn}$ onto amorphous silica present in marine diatoms have reported significantly greater enrichment of lighter $\mathrm{Zn}$ isotope $(-0.82 \%$ relative to IRMM 3702$)$ in the

142 aqueous phase than that observed in the present study with ferrihydrite. ${ }^{36}$ Similarly preferential 143 sorption of the heavy $\mathrm{Zn}$ isotope onto manganese oxyhydroxide has also been reported. ${ }^{37}$ The isotope 144 fractionation of $\mathrm{Zn}$ due to sorption onto mineral surfaces has been shown to depend on various factors, 145 including the ionic strength of the suspension, and aqueous speciation of $\mathrm{Zn}$ and the molecular 146 coordination environment. ${ }^{37,38}$ Aqueous chloro complexes of zinc preferentially contain light $\mathrm{Zn}$ isotopes, 147 and this drives the adsorbed pool to be heavier relative to the bulk solution ${ }^{37}$. Although $\mathrm{ZnCl}_{2}$ was used 148 as the starting solution in the present work, time-dependent changes in the isotopic ratio of $\mathrm{Zn}$ during 149 sorption onto ferrihydrite was not observed at $\mathrm{pH}$ 7.2. Future work investigating $\mathrm{Zn}$ isotope changes due 150 to uptake onto mineral surfaces should examine the effect of ionic strength.

Earlier spectroscopic studies indicated that the Zn ion physically sorbs onto ferrihydrite where it 152 retains its hydration shell resembling the spectrum of aqueous $\mathrm{Zn}^{2+}$ irrespective of $\mathrm{pH}$ and adsorbate

153 loading. ${ }^{39}$ The lack of isotope fractionation observed during the current study could be potentially 154 attributed to the unchanged $\mathrm{Zn}$ coordination during its uptake onto ferrihydrite. Alternatively an 155 equilibrium effect favoring heavier isotopes on the mineral surface balanced by a kinetic effect with 156 lighter isotopes moving/reacting faster (or vice versa) could potentially explain the absence of isotope 157 fractionation.

\subsection{Zn Precipitate Characterization and Isotope Fractionation}

159 The concentrations of $\mathrm{Zn}$ decreased in all the batch precipitation experiments with sulfide, carbonate, 160 and phosphate additions. Increasing concentrations of the counter-anion led to greater removal of $\mathrm{Zn}$ 
161 from solution (Figure S3). Time-dependent precipitation tests using a fixed counter-anion concentration 162 showed that equilibrium was attained in each experiment within less than 24 hours (Figure S4A). The pH 163 of the $\mathrm{Zn}$ carbonate and $\mathrm{Zn}$ phosphate suspensions remained circumneutral (Table S1). Geochemical 164 modeling using PHREEQC (WATEQ4 database) indicated that the formation of $\mathrm{Zn}(\mathrm{OH})_{2}$ is not favored at $165 \mathrm{pH}$ values $<7$ (Table S1). This condition is particularly important because $\mathrm{Zn}(\mathrm{OH})_{2}$ is known to 166 precipitate more rapidly than $\mathrm{ZnCO}_{3} \cdot{ }^{36}$ The $\mathrm{pH}$ of the sphalerite suspensions increased with increasing 167 sulfide concentration due to the basic nature of $\mathrm{Na}_{2} \mathrm{~S}$. Although PHREEQC calculations suggested the 168 formation of Zn sulfide (saturation index 11.93 as a mixture of sphalerite, wurtzite, and amorphous ZnS), 169 it also indicated the formation of $\mathrm{Zn}(\mathrm{OH})_{2}$ (saturation index 0.28$)$ at sulfide concentrations $>7 \mathrm{mM}(\mathrm{pH}>$ 170 7.15). It is important to note that although the predicted saturation indices indicate the feasibility of a 171 chemical reaction they do not indicate the rate of reaction. ${ }^{40}$ SEM examination showed distinct 172 morphology of the ZnS particles (Figure S5) with definite crystal boundaries resembling the bulk 173 structure of sphalerite ${ }^{41}$ reported in previous studies. X-ray powder diffraction further indicated the 174 presence of sphalerite (Figure S6) and the absence of $\mathrm{Zn}(\mathrm{OH})_{2}$. These observation suggest that the rate 175 of sphalerite formation was greater than the rate of precipitation of $\mathrm{Zn}(\mathrm{OH})_{2}$ although $\mathrm{pH}$ values $>7$ 176 were recorded in the precipitation tests at higher sulfide concentrations. The observed morphology 177 differs from the framboidal ZnS produced under sulfate reducing conditions in esturine sediments ${ }^{42}$ and 178 those found in biofilms. ${ }^{43}$

Distinct trends in isotope fractionation were observed during sphalerite precipitation relative to 180 the isotopic composition of the starting $\mathrm{ZnSO}_{4}$ solution $\left(\delta^{66} \mathrm{Zn}\right.$ of $-0.21 \pm 0.04 \%$ relative to IRMM 3702$)$. 181 The aqueous $\delta^{66} \mathrm{Zn}$ values of the $\mathrm{ZnSO}_{4}$ solution were found to increase systematically with increasing 182 sulfide concentrations during $\mathrm{Zn}$ sulfide precipitation (Figure 1) indicating an enrichment of ${ }^{66} \mathrm{Zn}$ with 183 respect to ${ }^{64} \mathrm{Zn}$. Although these precipitation studies were carried out at room temperature in batch 184 reactors using ultrapure reagents in a simple experimental matrix, the findings are consistent with field- 

207 water. $^{54}$

studies on hydrothermal systems that have also reported enrichment of the heavier isotope in the hydrothermal fluids $(-0.54-0.36 \% \text { relative to IRMM } 3702)^{44}$ and consequently inferred the preferential incorporation of lighter $\mathrm{Zn}$ isotopes into sphalerite. ${ }^{23,45}$ Studying $\delta^{66} \mathrm{Zn}$ during sphalerite precipitation in the laboratory can thus provide reasonable insights into environmental settings such as hydrothermal vents and ore deposits where factors such as temperature, pressure, composition of the source-rocks and kinetic fractionation have been shown to influence the zinc isotope composition of sphalerite. ${ }^{43-47}$

These findings indicate that aqueous $\mathrm{Zn}$ reservoirs may become enriched in heavier isotopes through abiotic precipitation of sphalerite, resulting in mineral phases with relatively light $\mathrm{Zn}$ isotope ratios. The stable isotope composition of $\mathrm{Zn}$ which occurs naturally in only one redox state may fractionate during precipitation with redox-sensitive species such as sulfur and can also be used as a diagnostic indicator of redox conditions. ${ }^{47}$

The $\mathrm{Zn}$ phosphate precipitates appeared as lamella of discrete rosettes composed of square sheets/plates (Figure S5), consistent with earlier studies. ${ }^{48,49}$ The powder x-ray diffraction pattern was consistent with hopeite $\left(\mathrm{Zn}_{3}\left(\mathrm{PO}_{4}\right)_{2} \cdot 4 \mathrm{H}_{2} \mathrm{O}\right)$ (Figure S6). The $\mathrm{Zn}$ carbonate precipitates were present as irregular aggregates with short, acicular crystals (Figure S5). The x-ray powder diffraction data indicated a structure consistent with hydrozincite $\left(\mathrm{Zn}_{5}\left(\mathrm{CO}_{3}\right)_{2}(\mathrm{OH})_{6}\right.$ and $\left.\mathrm{Zn}_{4} \mathrm{CO}_{3}(\mathrm{OH})_{6} \cdot \mathrm{H}_{2} \mathrm{O}\right)$ (Figure S6). The urchinlike morphology has been previously reported for hydrozincite. ${ }^{50,51}$ The relatively broad lines on the XRD spectra are indicative of the microcrystalline character of the hydrozincite sample. Hydrozincite and hopeite are environmentally relevant minerals and are known to form during $\mathrm{Zn}$ (II) sorption onto hydroxyapatite. ${ }^{52}$ Hydrozincite has also been reported to precipitate from mine waters due to the activity of photosynthetic microbes ${ }^{53}$ and during the dissolution of $\mathrm{ZnO}$ nanoparticles in carbonate-rich 
Zinc displayed similar isotopic behavior during the precipitation of hydrozincite and hopeite 209 relative to the isotopic composition of the starting solutions ( $\delta^{66} \mathrm{Zn}$ of $-0.14 \pm 0.03 \%$ ). The aqueous $\delta^{66} \mathrm{Zn}$ 210 values of the residual $\mathrm{ZnCl}_{2}$ solution were found to decrease during the precipitation of hydrozincite and 211 hopeite with increasing carbonate and phosphate concentrations respectively (Figure 1). The formation 212 of hydrozincite in mine drainage of Rio Naracauli, in Sardinia, Italy has been shown to produce waters 213 with lighter values of $\delta^{66} \mathrm{Zn}$ consistent with the aqueous ${ }^{66} \mathrm{Zn}$ behavior observed during hydrozincite 214 precipitation in the present study. ${ }^{55}$ consistent with studies showing enrichment of ${ }^{66} \mathrm{Zn}$ relative to ${ }^{64} \mathrm{Zn}$ in the root system of plants ${ }^{26,56}$ due 217 to the formation of Zn phosphate. ${ }^{57,58}$

218 Whereas the ${ }^{66} \mathrm{Zn}$ isotope data during $\mathrm{Zn}$ precipitation are generally consistent with field observations, 219 future research should focus on the role of other factors on $\mathrm{Zn}$ isotope fractionation such as 220 interactions with organic matter, uptake by biota, ionic strength, or sorption onto other mineral 221 surfaces, $\mathrm{pH}$, temperature, redox conditions and solution concentration and speciation. Although kinetic 222 isotope effects can potentially play a role in $\mathrm{Zn}$ isotope fractionation under certain conditions, the 223 observed isotopic behavior of $\mathrm{Zn}$ in the precipitation tests in this study is primarily attributed to 224 equilibrium effects. The trends in $\mathrm{Zn}$ isotope fractionation during time-dependent precipitation tests are 225 similar to the precipitation tests involving varied counter-anion concentrations (Figure S4B). The isotopic behavior of $\mathrm{Zn}$ during the precipitation of the three mineral phases can be 227 described using the Rayleigh fractionation model involving one reservoir and an isolated sink in a closed 228 system. ${ }^{14,35,59}$ The isotope fractionation values $(\varepsilon)$ for sphalerite, hydrozincite and hopeite were 229 calculated as $-0.30 \%$ o, $+0.18 \%$, and $+0.25 \%$ respectively. The data tends to deviate slightly from the 230 Rayleigh fractionation model towards smaller $F$ values where a large degree of isotope fraction is 
231 observed (Figure 1). This pattern is commonly observed when there is a finite pool of reactants typical of 232 those in closed systems.

The contrasting $\mathrm{Zn}$ isotope behavior observed during sphalerite precipitation vs hydrozincite and 234 hopeite can be used as indicators to deduce information about the composition and provenance of 235 environmental samples. ${ }^{35}$ The differences in isotopic behavior can be potentially attributed to 236 differences in the coordination environment of $\mathrm{Zn} .{ }^{60,44}$ The coordination of $\mathrm{Zn}(\mathrm{II})$ in aqueous solution is

237 usually octahedral that is characteristic of first-row transition metals. $\mathrm{Zn}(\mathrm{II})$ in sphalerite is tetrahedrally 238 coordinated with sulfur atoms. ${ }^{61}$ The tetrahedral coordination with sulfur is different than tetrahedral 239 coordination with oxygen due to the larger atomic radius $(0.88 \AA)$ and mass $(32.065)$ of sulfur atoms. In 240 contrast, $\mathrm{Zn}$ exhibits a combination of tetrahedral and octahedral coordination during the formation of 241 both hopeite and hydrozincite which can potentially explain the observed differences in $\mathrm{Zn}$ isotope 242 behaviour. ${ }^{61,62,63}$

\subsection{Environmental Implications}

Our study shows that $\mathrm{Zn}$ isotope ratios can be used as indicators to study selected precipitation

245 processes that lead to changes in aqueous $\mathrm{Zn}$. The loss of $\mathrm{Zn}$ from solution due to sphalerite 246 precipitation can be differentiated from loss due to carbonate/phosphate precipitation and adsorption,

247 because an increase in $\mathrm{Zn}$ isotope ratio implies sphalerite precipitation.

248 Over the past decade passive treatment techniques such as constructed wetlands, in situ treatment 249 systems, and permeable reactive barriers (PRBs) have been extensively employed for the remediation of 250 metal-impacted waters. ${ }^{64}$ The design of such facilities relies on subsurface flow of water and the 251 maintenance of permeable, anoxic conditions. Organic carbon is utilized in constructed wetland systems 252 and in situ treatment systems and PRBs to promote the growth and activity of sulfate reducing 253 organisms, leading to the formation of metal-sulfide minerals including sphalerite. The alkalinity 
generated in these biologically mediated systems also promotes the formation of metal carbonate

255 precipitates which could potentially include hydrozincite. ${ }^{65,66} \mathrm{Zn}$ stable isotope measurements may thus

256 be employed in treatment systems to understand pathways leading to the attenuation of $\mathrm{Zn}$ from

257 solution. However a range of other factors such as the presence of organic matter, secondary mineral

258 precipitates, ionic strength and speciation of $\mathrm{Zn}$, could influence the effectiveness of field

259 measurements. ${ }^{34,37}$ It is also important to note that although the precipitation results reported here

260 describe equilibrium isotope values, kinetic factors may also play a role in determining $\mathrm{Zn}$ isotope

261 fractionation in the environment.

$\mathrm{Zn}$ isotope ratios may be affected by processes that occur during weathering and transport. By

263 examining $\mathrm{Zn}$ isotope ratios one can potentially differentiate between sources of $\mathrm{Zn}$ and processes

264 involving $\mathrm{Zn}$ to gain insight into the weathering of mineral deposits and processes leading to $\mathrm{Zn}$

265 immobilization in surrounding areas. The findings presented in this work show the potential to use $\mathrm{Zn}$

266 isotope measurements as a complementary analytical technique to differentiate between dominant

267 processes resulting in $\mathrm{Zn}$ attenuation or mobility in the environment.

\section{ACKNOWLEDGEMENTS}

269 We thank Emma Buczolits, Joy Hu, and Heather Shrimpton at the University of Waterloo for their 270 support and assistance. We also thank Lei Zhang and Joseph P. Thomas from the WATLab for assistance 271 with electron microscopy. This project was funded by a Natural Sciences and Engineering Research 272 Council (NSERC) Strategic Project Grant awarded to D. Blowes and C. Ptacek.

273 ASSOCIATED CONTENT Supporting Information Available: Detailed information on the synthesis and 274 characterization of all the mineral phases is included in the supporting material. This material is available 275 free of charge via the Internet at http://pubs.acs.org.

276 The authors declare no competing financial interest. 


\section{References}

278

279

280

281

282

283

284

285

286

287

288

289

290

291

292

293

294

295

296

297

298

299

300

301

302

303

304

305

306

307

308

309

310

311

312

313

314

315

(1) Cloquet, C.; Carignan, J.; Lehmann, M. F.; Vanhaecke, F. Variation in the isotopic composition of zinc in the natural environment and the use of zinc isotopes in biogeosciences: A review. Anal. Bioanal. Chem. 2008, 390, 451-463.

(2) Sayen, S.; Guillon, E. Aging effect on Zn retention on a calcareous soil: Column experiments and synchrotron X-ray micro-spectroscopic investigation. Sci. Total Environ. 2014, 487, 545-556.

(3) Morel, F. M. M.; Reinfelder, J. R.; Roberts, S. B.; Chamberlain, C. P.; Lee, J. G.; Yee, D. Zinc and carbon co-limitation of marine phytoplankton. Nature 1994, 369, 740-742.

(4) Allen, J. G.; Masters, H. G.; Peet, R. L.; Mullins, K. R.; Lewis, R. D.; Skirrow, S. Z.; Fry, J. Zinc toxicity in ruminants. J. Comp. Pathol. 1983, 93, 363-377.

(5) Gräfe, M.; Sparks, D. L. Kinetics of zinc and arsenate co-sorption at the goethite-water interface. Geochim. Cosmochim. Acta 2005, 69, 4573-4595.

(6) Roberts, D. R.; Ford, R. G.; Sparks, D. L. Kinetics and mechanisms of Zn complexation on metal oxides using EXAFS spectroscopy. J. Colloid Interface Sci. 2003, 263, 364-376.

(7) Nachtegaal, M.; Marcus, M. A.; Sonke, J. E.; Vangronsveld, J.; Livi, K. J. T.; van Der Lelie, D.; Sparks, D. L. Effects of in situ remediation on the speciation and bioavailability of zinc in a smelter contaminated soil. Geochim. Cosmochim. Acta 2005, 69, 4649-4664.

(8) Saeed, M.; Fox, R. L. Influence of phosphate fertilization on zinc adsorption by tropical soils. Soil Sci. Soc. Am. J. 1979, 43, 683-686.

(9) Sharpless, R. G.; Wallihan, E. F.; Peterson, F. F. Retention of zinc by some arid zone soil materials treated with zinc sulfate. Soil Sci. Soc. Am. J. 1969, 33, 901-904.

(10) Schindler, P.; Reinert, M.; Gamsjäger, H. Zur Thermodynamik der metallcarbonate. löslichkeitskonstanten und freie bildungsenthalpien von $\mathrm{ZnCO}_{3}$ und $\mathrm{Zn}_{5}(\mathrm{OH})_{6}\left(\mathrm{CO}_{3}\right)_{2}$ bei $25^{\circ}$. Helv. Chim. Acta 1969, 52, 2327-2332.

(11) Wieser, M. E.; Schwieters, J. B. The development of multiple collector mass spectrometry for isotope ratio measurements. Int. J. Mass Spectrom. 2005, 242, 97-115.

(12) Balistrieri, L. S.; Borrok, D. M.; Wanty, R. B.; Ridley, W. I. Fractionation of Cu and Zn isotopes during adsorption onto amorphous Fe(III) oxyhydroxide: Experimental mixing of acid rock 
drainage and ambient river water. Geochim. Cosmochim. Acta 2008, 72, 311-328.

(13) Pokrovsky, O. S.; Viers, J.; Freydier, R. Zinc stable isotope fractionation during its adsorption on oxides and hydroxides. J. Colloid Interface Sci. 2005, 291, 192-200.

(14) Juillot, F.; Maréchal, C.; Ponthieu, M.; Cacaly, S.; Morin, G.; Benedetti, M.; Hazemann, J. L.; Proux, O.; Guyot, F. Zn isotopic fractionation caused by sorption on goethite and 2-Lines ferrihydrite. Geochim. Cosmochim. Acta 2008, 72, 4886-4900.

(15) Rodushkin, I.; Stenberg, A.; Andrén, H.; Malinovsky, D.; Baxter, D. C. Isotopic Fractionation during Diffusion of Transition Metal Ions in Solution. Anal. Chem. 2004, 76, 2148-2151.

(16) Kafantaris, F. C. A; Borrok, D. M. Zinc isotope fractionation during surface adsorption and intracellular incorporation by bacteria. Chem. Geol. 2014, 366, 42-51.

(17) Pichat, S.; Douchet, C.; Albarède, F. Zinc isotope variations in deep-sea carbonates from the eastern equatorial Pacific over the last 175 ka. Earth Planet. Sci. Lett. 2003, 210, 167-178.

(18) Arnold, T.; Schönbächler, M.; Rehkämper, M.; Dong, S.; Zhao, F. J.; Kirk, G. J. D.; Coles, B. J.; Weiss, D. J. Measurement of zinc stable isotope ratios in biogeochemical matrices by doublespike MC-ICPMS and determination of the isotope ratio pool available for plants from soil. Anal. Bioanal. Chem. 2010, 398, 3115-3125.

(19) Maréchal, C. N.; Nicolas, E.; Douchet, C.; Albarède, F. Abundance of zinc isotopes as a marine biogeochemical tracer. Geochemistry Geophys. Geosystems 2000, 1, 1-15.

(20) Chen, J.; Gaillardet, J.; Louvat, P. Zinc isotopes in the Seine River waters, France: A probe of anthropogenic contamination. Environ. Sci. Technol. 2008, 42, 6494-6501.

(21) Borrok, D. M.; Wanty, R. B.; Ian Ridley, W.; Lamothe, P. J.; Kimball, B. a.; Verplanck, P. L.; Runkel, R. L. Application of iron and zinc isotopes to track the sources and mechanisms of metal loading in a mountain watershed. Appl. Geochemistry 2009, 24, 1270-1277.

(22) Aucour, A.-M.; Bedell, J.-P.; Queyron, M.; Magnin, V.; Testemale, D.; Sarret, G. Dynamics of Zn in an urban wetland soil-plant system: Coupling isotopic and EXAFS approaches. Geochim. Cosmochim. Acta 2015, 160, 55-69.

(23) Kelley, K. D.; Wilkinson, J. J.; Chapman, J. B.; Crowther, H. L.; Weiss, D. J. Zinc isotopes in sphalerite from base metal deposits in the Red Dog District, Northern Alaska. Econ. Geol. 2009, 104, 767-773. 
(24) Matthies, R.; Blowes, D. The zinc stable isotope signature of waste rock drainage in Arctic Canada. Appl. Geochemistry 2014, 16, 2014.

(25) Bermin, J.; Vance, D.; Archer, C.; Statham, P. J. The determination of the isotopic composition of $\mathrm{Cu}$ and $\mathrm{Zn}$ in seawater. Chem. Geol. 2006, 226, 280-297.

(26) Weiss, D. J.; Mason, T. F. D.; Zhao, F. J.; Kirk, G. J. D.; Coles, B. J.; Horstwood, M. S. a. Isotopic discrimination of zinc in higher plants. New Phytol. 2005, 165, 703-710.

(27) Antelo, J.; Arce, F.; Fiol, S. Arsenate and phosphate adsorption on ferrihydrite nanoparticles. Synergetic interaction with calcium ions. Chem. Geol. 2015, 410, 53-62.

(28) Parkhurst, D. L.; Appelo, C. A. J. User's guide to PHREEQC (Version 2) : A computer program for speciation, batch-reaction, one-dimensional transport, and inverse geochemical calculations, ed.; 1999.

(29) Ball, J. W.; Nordstrom, D. K. WATEQ4F -- User's manual with revised thermodynamic data base and test cases for calculating speciation of major, trace and redox elements in natural waters, ed.; 1991.

(30) Maréchal, C. N.; Télouk, P.; Albarède, F. Precise analysis of copper and zinc isotopic compositions by plasma-source mass spectrometry. Chem. Geol. 1999, 156, 251-273.

(31) Brinza, L.; Benning, L. G.; Statham, P. J. Adsorption studies of Mo and V onto ferrihydrite. Mineral. Mag. 2008, 72, 385-388.

(32) Rout, K.; Mohapatra, M.; Anand, S. 2-Line Ferrihydrite: synthesis, characterization and its adsorption behaviour for removal of $\mathrm{Pb}(\mathrm{II}), \mathrm{Cd}(\mathrm{II}), \mathrm{Cu}(\mathrm{II})$ and $\mathrm{Zn}(\mathrm{II})$ from aqueous solutions. Dalt. Trans. 2012, 41, 3302.

(33) Nachtegaal, M.; Sparks, D. L. Effect of iron oxide coatings on zinc sorption mechanisms at the clay-mineral/water interface. J. Colloid Interface Sci. 2004, 276, 13-23.

(34) Jouvin, D.; Louvat, P.; Juillot, F.; Maréchal, C. N.; Benedetti, M. F. Zinc isotopic fractionation: Why organic matters. Environ. Sci. Technol. 2009, 43, 5747-5754.

(35) Wiederhold, J. G. Metal stable isotope signatures as tracers in environmental geochemistry. Environ. Sci. Technol. 2015, 49, 2606-2624.

(36) Gélabert, A.; Pokrovsky, O. S.; Viers, J.; Schott, J.; Boudou, A.; Feurtet-Mazel, A. Interaction between zinc and freshwater and marine diatom species: Surface complexation and $\mathrm{Zn}$ isotope 
fractionation. Geochim. Cosmochim. Acta 2006, 70, 839-857.

(37) Bryan, A. L.; Dong, S.; Wilkes, E. B.; Wasylenki, L. E. Zinc isotope fractionation during adsorption onto Mn oxyhydroxide at low and high ionic strength. Geochim. Cosmochim. Acta 2015, 157, 182-197.

(38) Little, S. H.; Sherman, D. M.; Vance, D.; Hein, J. R. Molecular controls on Cu and Zn isotopic fractionation in Fe-Mn crusts. Earth Planet. Sci. Lett. 2014, 396, 213-222.

(39) Trivedi, P.; Axe, L.; Tyson, T. A. An Analysis of Zinc Sorption to Amorphous versus Crystalline Iron Oxides Using XAS. J. Colloid Interface Sci. 2001, 244, 230-238.

(40) Zhu, C. Geochemical Modeling of Reaction Paths and Geochemical Reaction Networks. Rev. Mineral. Geochemistry 2009, 70, 533-569.

(41) Jordan, G.; Pokrovsky, O. S.; Bahlo, J.; Guichet, X.; Schlueter, C. Sphalerite dissolution kinetics at low hydrothermal conditions. Chem. Geol. 2011, 286, 272-279.

(42) Luther, G. W.; Meyerson, a. L.; Krajewski, J. J.; Hires, R. Metal Sulfides in Estuarine Sediments. J. Sediment. Res. 1980, Vol. 50, 1117-1120.

(43) Labrenz, M.; Druschel, G. K.; Thomsen-Ebert, T.; Gilbert, B.; Welch, S. a; Kemner, K. M.; Logan, G. a; Summons, R. E.; De Stasio, G.; Bond, P. L.; et al. Formation of sphalerite (ZnS) deposits in natural biofilms of sulfate-reducing bacteria. Science 2000, 290, 1744-1747.

(44) John, S. G.; Rouxel, O. J.; Craddock, P. R.; Engwall, A. M.; Boyle, E. A. Zinc stable isotopes in seafloor hydrothermal vent fluids and chimneys. Earth Planet. Sci. Lett. 2008, 269, 17-28.

(45) Wilkinson, J. J.; Weiss, D. J.; Mason, T. F. D.; Coles, B. J. Zinc isotope variation in hydrothermal systems: Preliminary evidence from the Irish midlands ore field. Econ. Geol. 2005, 100, 583-590.

(46) Pašava, J.; Tornos, F.; Chrastný, V. Zinc and sulfur isotope variation in sphalerite from carbonatehosted zinc deposits, Cantabria, Spain. Miner. Depos. 2014, 49, 797-807.

(47) Schauble, E. Applying stable isotope fractionation theory to new systems. Rev. Mineral. Geochemistry 2004, 55, 65.

(48) Giuseppina, A.; Emma, A.; Paolo, B.; Gianfranca, G. Constitution and corrosion resistance of phosphate protective coatings. Metall. Sci. Technol. 1983, 1, 58-63. 
(49) Bubert, H.; Pulm, H.; Puderbach, H. Investigations on hopeite- and phosphophyllite-containing phosphate coatings on steel. Microchim. Acta 1987, 91, 355-364.

(50) Chen, M.; Wang, Y.; Song, L.; Gunawan, P.; Zhong, Z.; She, X.; Su, F. Urchin-like ZnO microspheres synthesized by thermal decomposition of hydrozincite as a copper catalyst promoter for the Rochow reaction. RSC Adv. 2012, 2, 4164.

(51) De Giudici, G.; Podda, F.; Sanna, R.; Musu, E.; Tombolini, R.; Cannas, C.; Musinu, A.; Casu, M. Structural properties of biologically controlled hydrozincite: An HRTEM and NMR spectroscopic study. Am. Mineral. 2009, 94, 1698-1706.

(52) Lee, Y. J.; Elzinga, E. J.; Reeder, R. J. Sorption mechanisms of zinc on hydroxyapatite: Systematic uptake studies and EXAFS spectroscopy analysis. Environ. Sci. Technol. 2005, 39, 4042-4048.

(53) Podda, F.; Zuddas, P.; Minacci, A.; Baldi, F.; Pepi, M. Heavy metal coprecipitation with hydrozincite $\left[\mathrm{Zn}_{5}\left(\mathrm{CO}_{3}\right)_{2}(\mathrm{OH})_{6}\right]$ from mine waters caused by photosynthetic microorganisms. Appl. Environ. Microbiol. 2000, 5, 5092-5098.

(54) Sivry, Y.; Gelabert, a.; Cordier, L.; Ferrari, R.; Lazar, H.; Juillot, F.; Menguy, N.; Benedetti, M. F. Behavior and fate of industrial zinc oxide nanoparticles in a carbonate-rich river water. Chemosphere 2014, 95, 519-526.

(55) Wanty, R. B.; Podda, F.; De Giudici, G.; Cidu, R.; Lattanzi, P. Zinc isotope and transition-element dynamics accompanying hydrozincite biomineralization in the Rio Naracauli, Sardinia, Italy. Chem. Geol. 2013, 337-338, 1-10.

(56) Fujii, T.; Albarède, F. Ab initio calculation of the $\mathrm{Zn}$ isotope effect in phosphates, citrates, and malates and applications to plants and soil. PLoS One 2012, 7, e30726.

(57) Sarret, G.; Saumitou-Laprade, P.; Bert, V.; Proux, O.; Hazemann, J.-L.; Traverse, A.; Marcus, M. A.; Manceau, A. Forms of zinc accumulated in the hyperaccumulator Arabidopsis halleri. Plant Physiol. 2002, 130, 1815-1826.

(58) Aucour, A. M.; Pichat, S.; Macnair, M. R.; Oger, P. Fractionation of stable zinc isotopes in the zinc hyperaccumulator Arabidopsis halleri and nonaccumulator Arabidopsis petraea. Environ. Sci. Technol. 2011, 45, 9212-9217.

(59) Weiss, D. J.; Harris, C.; Maher, K.; Bullen, T. A teaching exercise to introduce stable isotope fractionation of metals into geochemistry courses. J. Chem. Educ. 2013, 90, 1014-1017.

(60) Fujii, T.; Moynier, F.; Pons, M. L.; Albarède, F. The origin of Zn isotope fractionation in sulfides. Geochim. Cosmochim. Acta 2011, 75, 7632-7643. 
478 (61) Vaughan, D.; Tossell, J. Electronic structures of sulfide minerals - Theory and experiment. Phys. Chem. Miner. 1983, 9, 253-262.

(62) Ghose, S. The crystal structure of hydrozincite, $\mathrm{Zn}_{5}(\mathrm{OH}) \cdot 6\left(\mathrm{CO}_{3}\right)_{2}$. Acta Crystallogr. 1964, 17, 10511057.

483

484

(63) Liebau, F. Zur Kristallstruktur des Hopeits, $\mathrm{Zn}_{3}\left(\mathrm{PO}_{4}\right)_{2} \cdot 4 \mathrm{H}_{2} \mathrm{O}$. Acta Crystallogr. 1965, 18, 352-354.

485

486

(64) Obiri-Nyarko, F.; Grajales-Mesa, S. J.; Malina, G. An overview of permeable reactive barriers for in

(65) Remoudaki, E.; Hatzikioseyian, A.; Kousi, P.; Tsezos, M. The mechanism of metals precipitation by

(66) Khoshnoodi, M.; Dipple, G.; Baldwin, S. A. Mineralogical study of a biologically-based treatment 


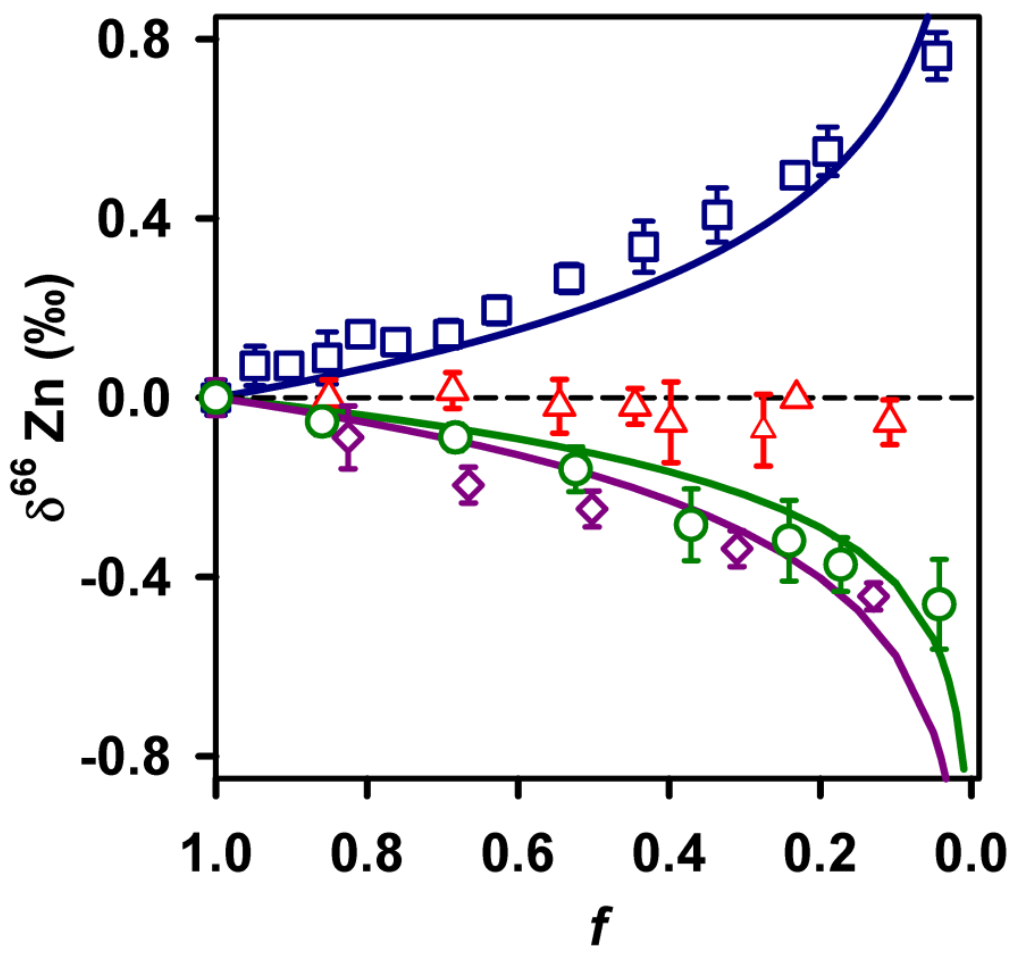

509 Figure 1: Isotope fractionation $\left(\delta^{66}\right)$ of $\mathrm{Zn}$ relative to the input solutions during $(\Delta)$ sorption onto

510 ferrihydrite; precipitation of $\mathrm{Zn}$ sulfide as sphalerite ( $\square) \boldsymbol{E}=-\mathbf{0 . 3 0} \%$; $\mathrm{Zn}$ carbonate as hydrozincite (O)

$511 \varepsilon=0.18 \%$; and $\mathrm{Zn}$ phosphate as hopeite $(\diamond) \boldsymbol{\varepsilon}=0.25 \%$; where $\mathrm{f}$ is the fraction of $\mathrm{Zn}$ remaining in

512 solution. The error bars represent $2 \sigma$ from three analytical events. The solid blue, green and purple

513 lines represent the best-fit Rayleigh models. Symbols where error bars are not seen indicate small 514 error bars. 
518 TOC Graphics

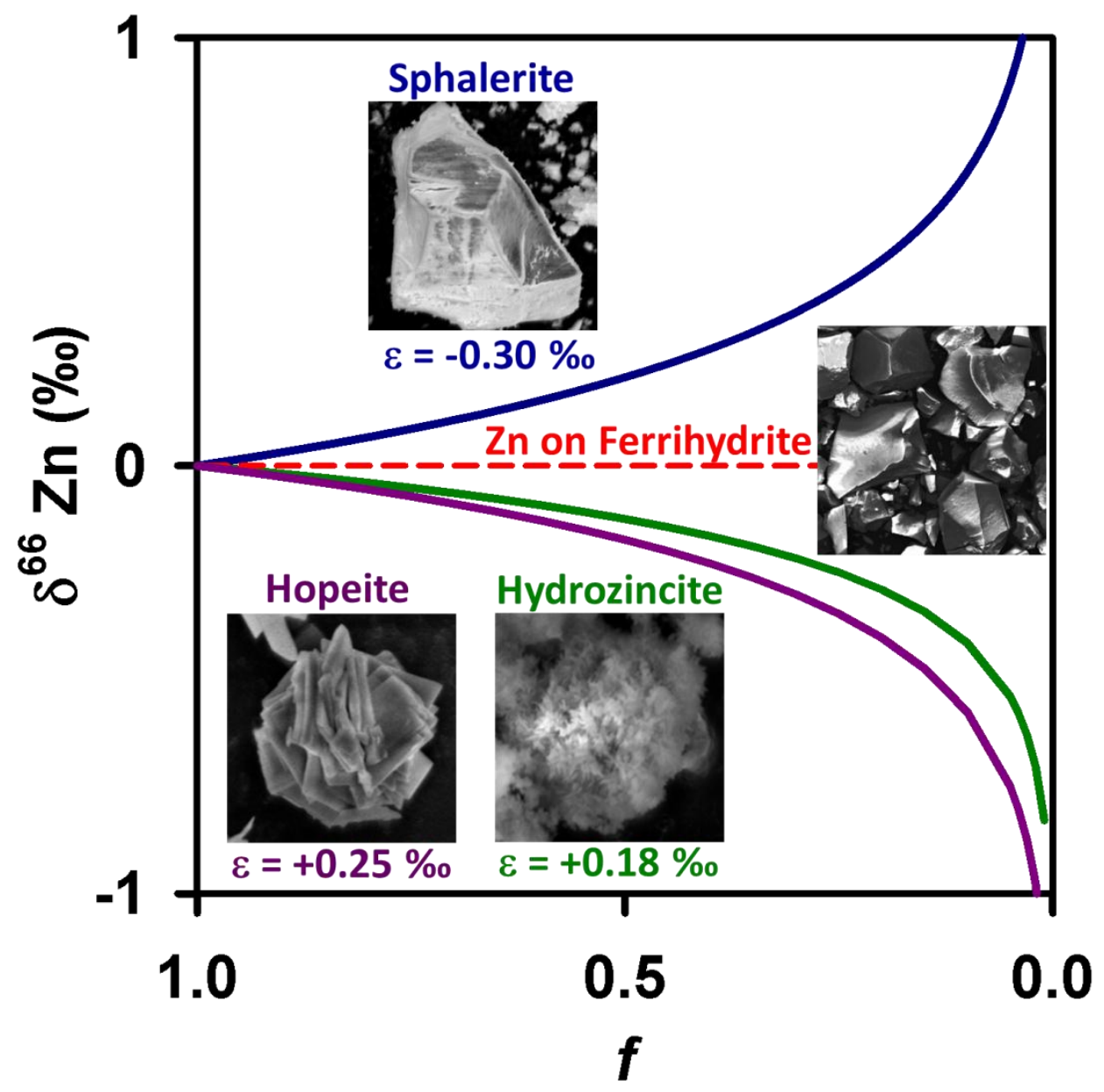


Zinc isotope fractionation as an indicator of geochemical attenuation processes

Harish Veeramani ${ }^{1+*}$, Jane Eagling ${ }^{1}$, Julia H. Jamieson-Hanes ${ }^{1}$, Lingyi Kong ${ }^{1}$, Carol J. Ptacek ${ }^{1}$ and David W Blowes $^{1}$

${ }^{1}$ Department of Earth and Environmental Sciences

University of Waterloo

200 University Avenue West

Waterloo, Ontario

Canada N2L 3G1

*harish.veeramani@uwaterloo.ca

†Present Address:

School of Engineering

University of Glasgow

Glasgow G12 8QQ

United Kingdom

Phone: +44(0)141-330-1839

Email: harish.veeramani@glasgow.ac.uk

\section{SUPPORTING INFORMATION}




\section{Iron Oxide Synthesis}

A batch of 2-line ferrihydrite was synthesized according to the method described by Antelo and co-workers. ${ }^{1}$ Briefly, $40 \mathrm{~g}$ of unhydrolyzed crystals of $\mathrm{Fe}\left(\mathrm{NO}_{3}\right)_{3}$ were dissolved in $500 \mathrm{~mL}$ deionized water that was vigorously stirred during the addition of $350 \mathrm{~mL}$ of $1 \mathrm{M} \mathrm{KOH} \mathrm{(pH} \mathrm{7.5).} \mathrm{The} \mathrm{resulting} \mathrm{precipitate}$ was washed ten times by centrifugation (10000 G for 15 minutes) and lyophilized (Labconco) for 24 hours and stored at $-20^{\circ} \mathrm{C}$. Each batch of ferrihydrite was used within a week following preparation to prevent phase transformation to goethite. Samples of ferrihydrite were periodically checked by X-ray diffraction (XRD) to ensure the absence of goethite (Figure S1).

\section{Zinc Precipitation Experiments}

Zinc sulfide was precipitated in a series of batch experiments involving $8 \mathrm{mM} \mathrm{ZnSO}_{4}\left(523 \mathrm{mg} \mathrm{L}^{-1}\right)$ that was amended with varying concentrations of $\mathrm{Na}_{2} \mathrm{~S}_{2}$. An acidic solution of $\mathrm{ZnSO}_{4}$ (pH c.a. 3) was purged for several hours with ultra-pure argon to exclude atmospheric $\mathrm{CO}_{2}$. The addition of $\mathrm{Na}_{2} \mathrm{~S}_{2}$ to batches of $\mathrm{ZnSO}_{4}$ was carried out gravimetrically in screw-cap centrifuge tubes. The tubes containing the reaction mixture were allowed to stand for 24 hours inside an anoxic glove-box (Coy Laboratory Products, Grass Lake, MI) with occasional shaking.

The precipitation tests for $\mathrm{Zn}$ carbonate hydroxide and $\mathrm{Zn}$ phosphate were similar to $\mathrm{Zn}$ sulfide in that an acidic and anoxic solution of $8 \mathrm{mM} \mathrm{ZnCl}_{2}$ was amended with varying concentrations of $\mathrm{NaHCO}_{3}$ and $\mathrm{Na}_{3} \mathrm{PO}_{4}$, respectively in a series of batch experiments. Although spontaneous $\mathrm{Zn}$ precipitation was observed under all test conditions, the centrifuge tubes containing $\mathrm{Zn}$ sulfide, $\mathrm{Zn}$ carbonate, and $\mathrm{Zn}$ phosphate were allowed to remain in the anoxic glove-box for 24 hours prior to centrifugation and filtration. The tubes were centrifuged at 6000 XG for 20 minutes and filtered using $0.2 \mu \mathrm{m}$ PES filters. The $\mathrm{pH}$ of the supernatant was measured and a subset of the filtrate was tested for alkalinity. The remaining filtrate was acidified for bulk aqueous chemistry and isotope analysis. Total alkalinity was 
measured using a $\mathrm{HACH}$ digital titrator (Model 16900) and titrated with $0.16 \mathrm{~N} \mathrm{H}_{2} \mathrm{SO}_{4}$ to an endpoint of pH 4.5 using bromocresol green-methyl red as a pH indicator.

\section{Solid Phase Characterization}

\subsection{SEM}

The morphologies of the $\mathrm{Zn}$ precipitates were observed using a Zeiss Ultra scanning electron microscope (SEM) at the Waterloo Advanced Technology Laboratory (WATLab). The Zn precipitates were freeze-dried and the dry powder was loaded onto SEM sample stubs. A layer of carbon tape was applied to the sample stubs before loading the samples. The images were acquired at a working distance of 10 millimeters using an in-lens detector. Selected samples were sputter-coated briefly with Au to minimize sample charging during image acquisition.

\subsection{X-ray diffraction (XRD)}

The structure of the solid phase precipitates was confirmed using a Bruker D8 Focus X-Ray Diffractometer (XRD) equipped with a $\mathrm{Cu}$ Ka source. Measurements were carried out using a step-time of 1 s, step-size of 0.05 ranging from 5 to 90 2-theta. Background subtraction and peak identification were carried out using the Diffrac.Suite EVA software.

\subsection{Synchrotron powder diffraction (SRPD)}

A sample of ferrihydrite was ground in a clean mortar and pestle and loaded into polyimide capillary tubes (Cole-Parmer: 95820-06). The ends of the tube were sealed using glue (Loctite 454) and the samples were analyzed at beamline 08B1-1 (CMCF-BM) at the Canadian Light Source. Diffraction data was collected from 5 to $402 \theta$ using a wavelength $(\lambda)$ of $0.688 \AA$. The data was processed using the GSAS-II Crystallography data analysis software. ${ }^{2}$ 


\section{MC-ICP-MS analysis}

Samples were combined with a double-spike solution of known isotopic composition (Isoflex, San Francisco, USA, $67 \mathrm{Zn}: 70 \mathrm{Zn}=0.43: 0.57$, spike:sample ratio of 0.37 ) and converted to an $\mathrm{HCl}$ matrix via evaporation. Spike-sample mixtures were loaded onto columns containing $1.6 \mathrm{~mL}$ of AG-MP-1M anion-exchange resin (100-200 mesh; Bio-Rad, USA). Unwanted matrix elements were eluted with progressively decreasing concentrations of $\mathrm{HCl}$; $\mathrm{Zn}$ was eluted in $0.5 \mathrm{M} \mathrm{HCl}$ during the final step of the purification scheme. The eluted $\mathrm{Zn}$ fraction was evaporated and re-dissolved in $5 \mathrm{M} \mathrm{HNO}_{3}$ twice to ensure complete removal of chlorine ions and converted back to a $\mathrm{HNO}_{3}$ matrix via evaporation. Each sample was purified in duplicate and the duplicates were analyzed during three analytical events; the final value for each sample was calculated as the average of six replicate measurements. High-precision $\mathrm{Zn}$ isotope measurements were performed using a multi-collector inductively-coupled plasma mass spectrometer (MC-ICP-MS; Thermo Scientific Neptune). 


\section{Results}

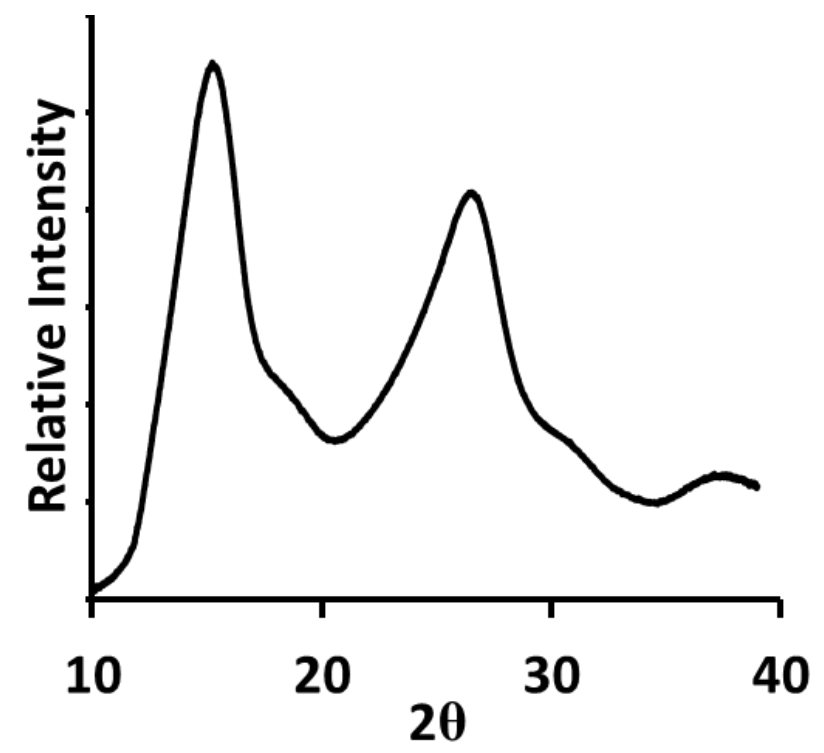

Figure S1: Synchrotron powder diffraction of synthetic ferrihydrite. The diffractogram shows two broad reflections at $2 \theta=15.23$ and 26.55 corresponding to interplanar distances ( $d$-spacing) of $d=2.58$ and $1.49 \AA$ respectively. The diffraction pattern is similar to that reported by Carta and coworkers for synthetic 2 -line ferrihydrite nanoparticles ${ }^{3}$.

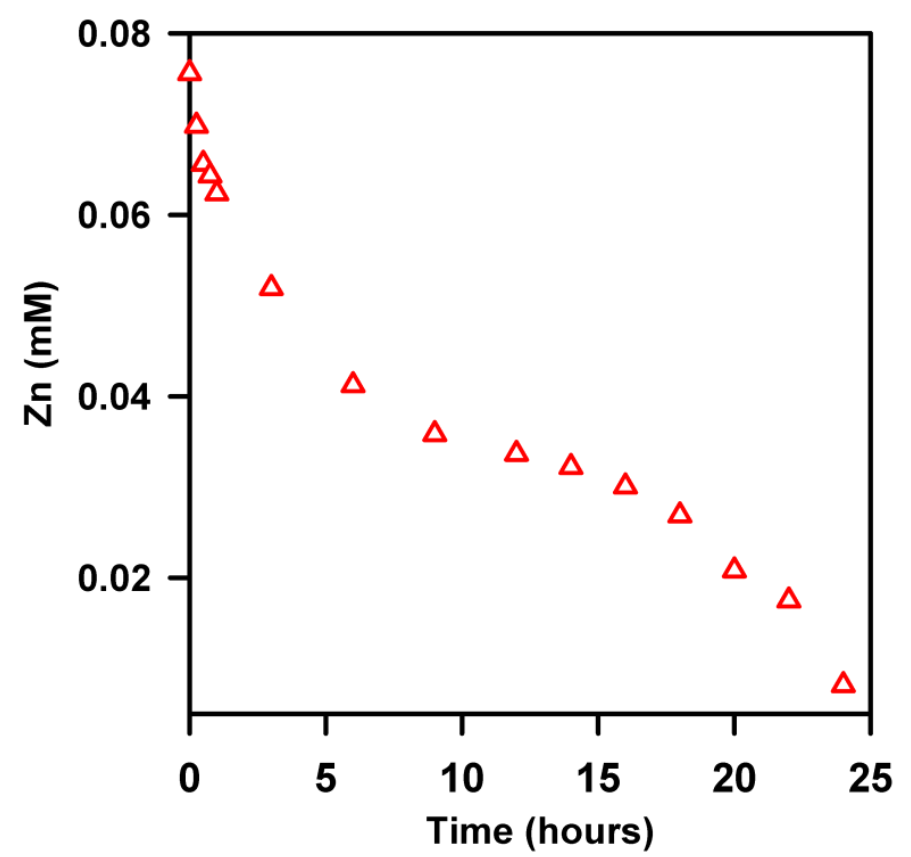

Figure S2: Time-dependent adsorption of Zn on ferrihydrite. The concentration of ferrihydrite was 2.0 grams/L and the $\mathrm{pH}$ of the suspension was maintained at 7.2. 


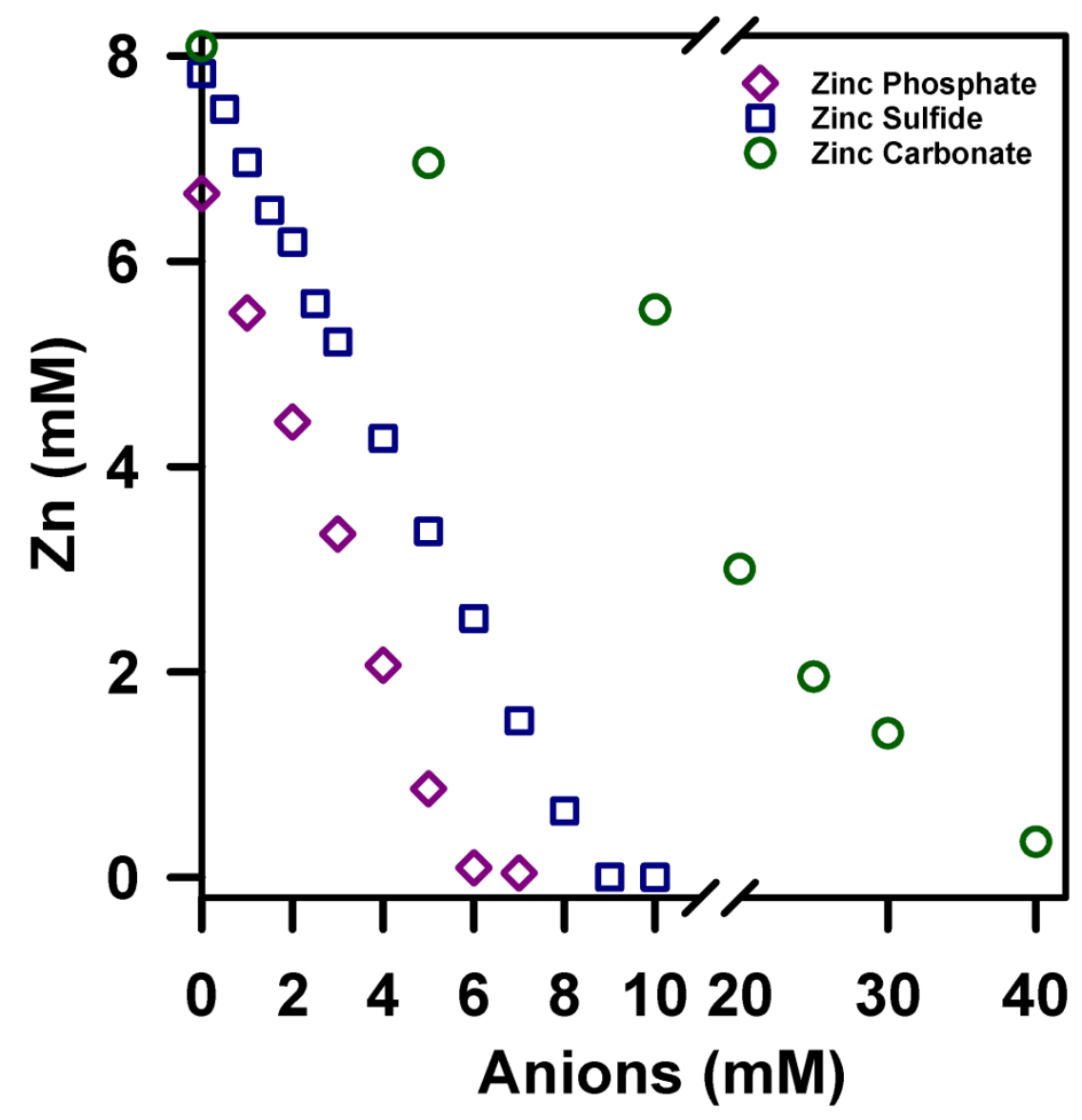

Figure S3: Zinc removal from solution due to precipitation with sulfide( $(\mathbf{\square})$, carbonate $(\mathbf{O})$ and phosphate $(\diamond)$. 
A

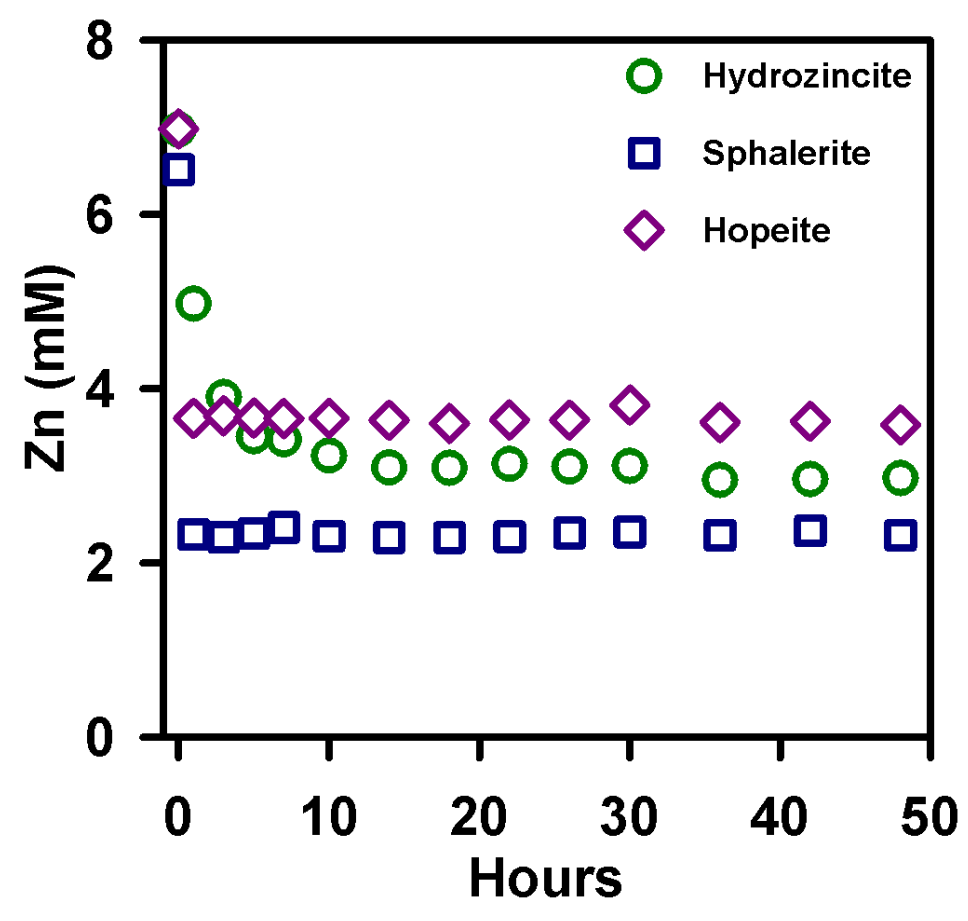

B

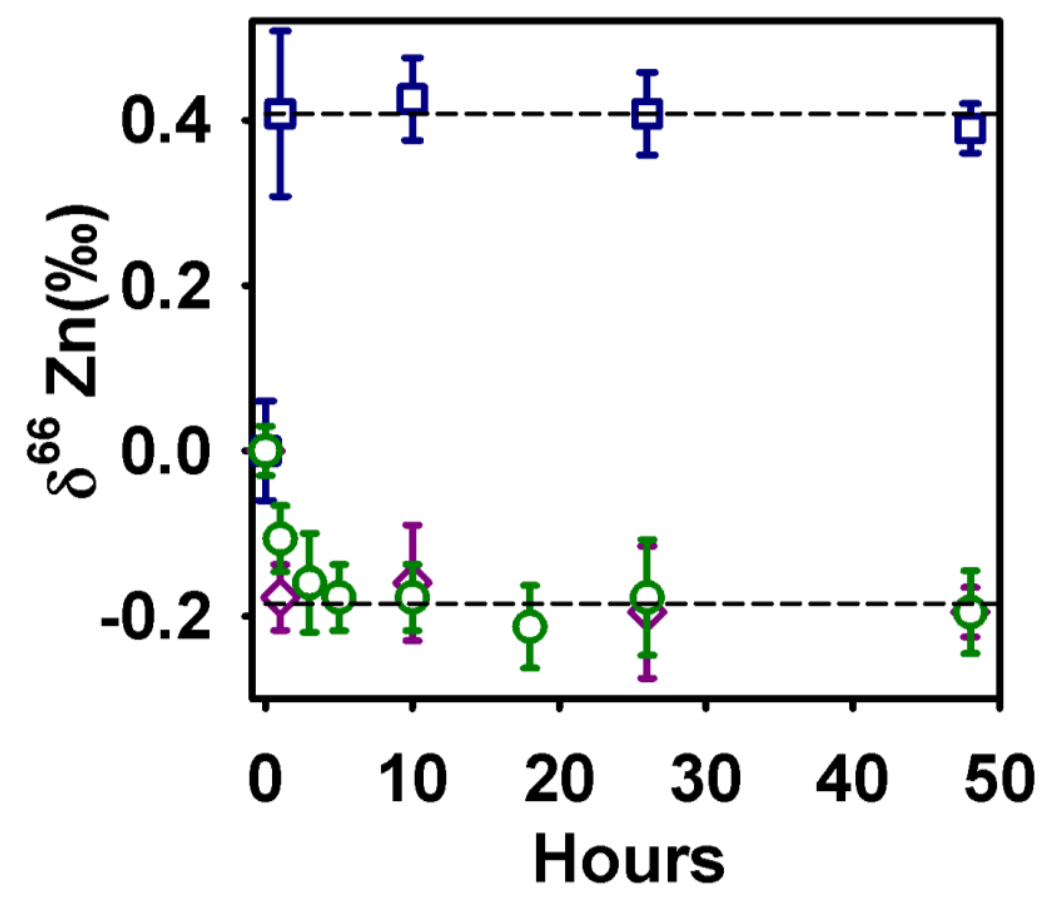

Figure S4: A) Time-dependent precipitation of sphalerite, hopeite and hydrozincite using fixed counter-anion concentration. B) Isotope analysis of selected samples showing isotope equilibrium. Zinc isotope equilibrium was reached immediately during the formation of Sphalerite and Hopeite. In case of hydrozincite, isotope equilibrium was reached within 6 hours. 

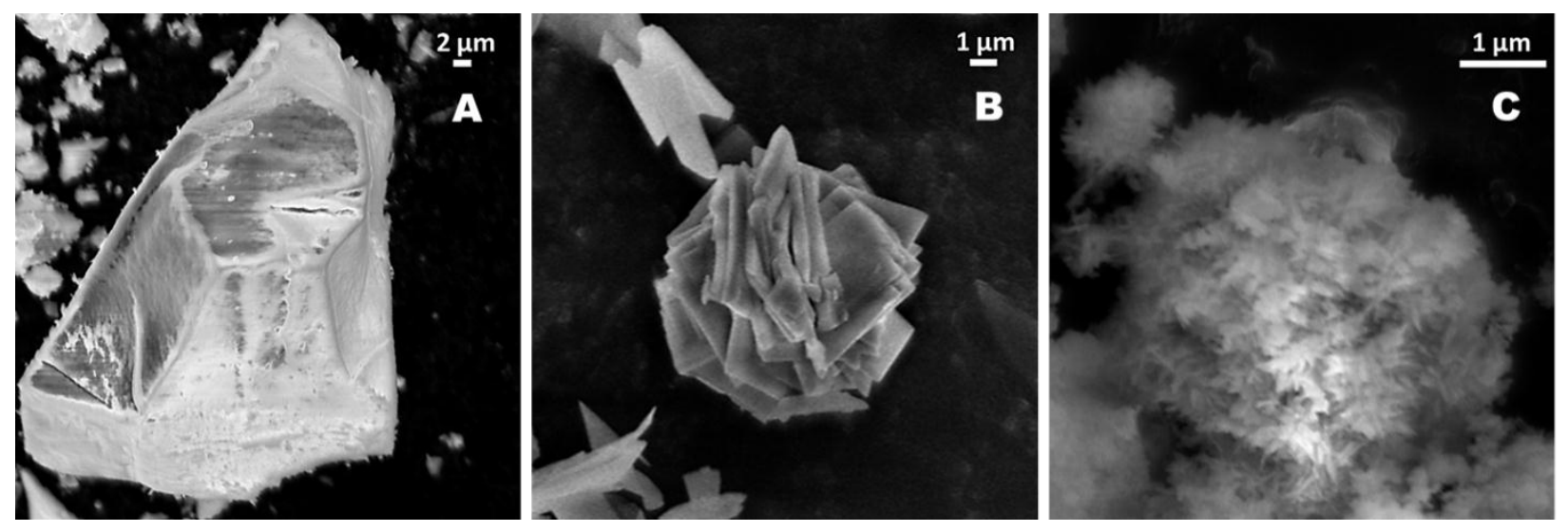

Figure S5: Scanning electron microscopy images of the Zn precipitates; (A) Zn sulfide as sphalerite (B) Zn phosphate as hopeite and (C) Zn hydroxycarbonate as hydrozincite. 


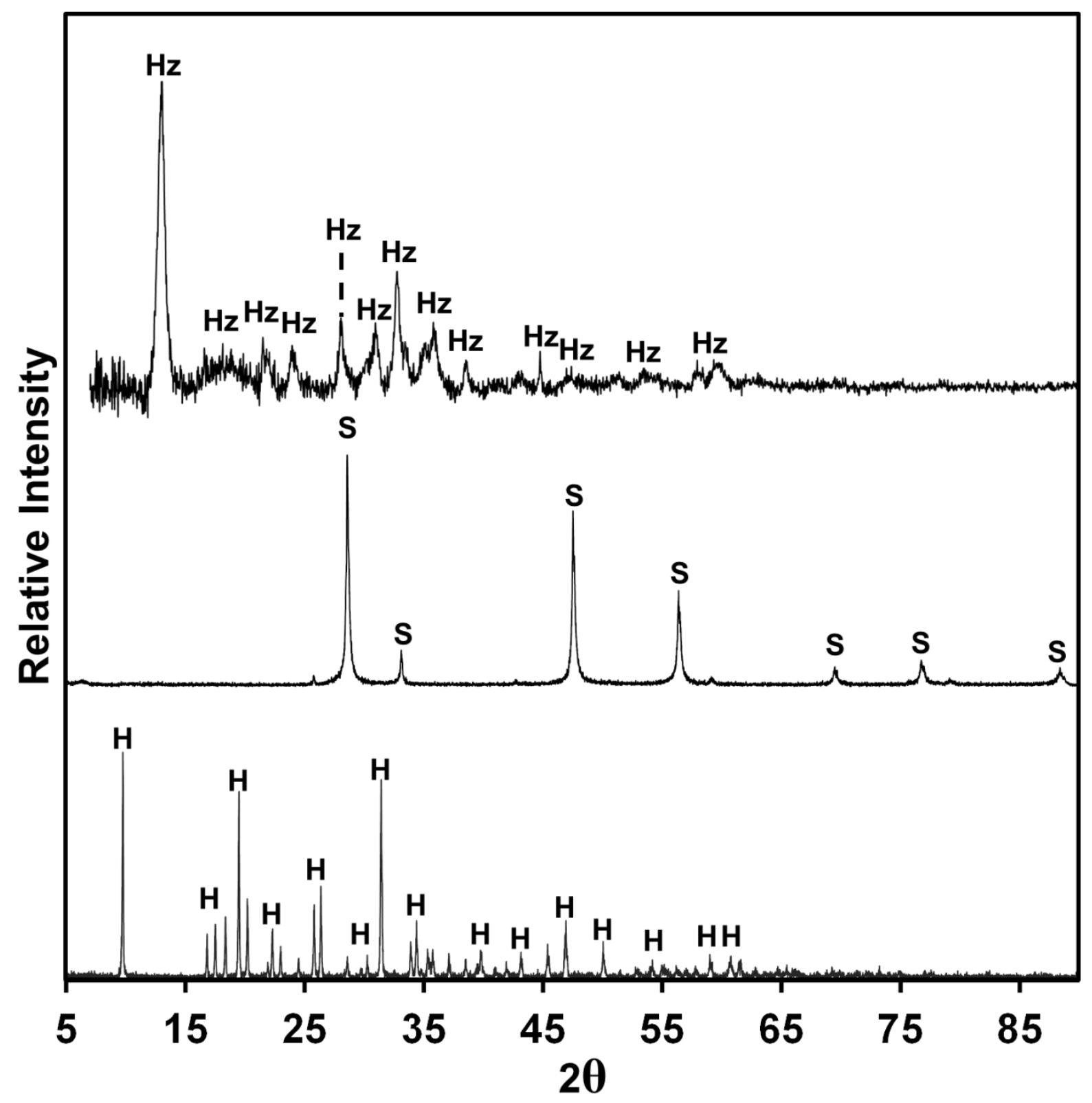

Figure S6: X-ray diffraction confirming the identity of zinc precipitates. The major peaks for each phase is highlighted; hopeite $(\mathrm{H})$, sphalerite $(\mathrm{S})$ and hydrozincite $(\mathrm{Hz})$. 
Table S1: Compilation of $\mathrm{pH}$, alkalinity, counter-anion concentration, concentration of $\mathrm{Zn}$ and $\delta^{66} \mathrm{Zn}$ in the reacted solution following zinc precipitation and zinc sorption experiments. (ND $=$ Not Determined)

\begin{tabular}{|c|c|c|c|c|c|c|c|c|c|c|c|}
\hline $\begin{array}{c}\text { Phosphate } \\
\text { mM }\end{array}$ & $\begin{array}{c}\text { Final } \\
\text { pH }\end{array}$ & $\begin{array}{c}\text { Alkalinity as } \\
\mathrm{CaCO}_{3} \\
\left(\mathrm{mg} \mathrm{L}^{-1}\right)\end{array}$ & $\begin{array}{c}\mathrm{Zn}(\mathrm{mM}) \\
\text { Unreacted } \\
\text { Solution }\end{array}$ & $\begin{array}{c}\delta^{66} \mathrm{Zn} \\
\text { Unreacted } \\
\text { Solution }\end{array}$ & $2 \sigma(\%)$ & $\begin{array}{c}\text { Carbonate } \\
\mathrm{mM}\end{array}$ & Final pH & $\begin{array}{c}\text { Alkalinity as } \\
\mathrm{CaCO}_{3} \\
\left(\mathrm{mg} \mathrm{L}^{-1}\right)\end{array}$ & $\begin{array}{l}\mathrm{Zn}(\mathrm{mM}) \\
\text { Unreacted } \\
\text { Solution }\end{array}$ & $\begin{array}{c}\delta^{66} \mathrm{Zn} \\
\text { Unreacted } \\
\text { Solution }\end{array}$ & $2 \sigma(\%)$ \\
\hline 1 & 5.71 & 25 & 5.5 & -0.09 & 0.07 & 5 & 6.63 & 110 & 7 & -0.05 & 0.03 \\
\hline 2 & 5.68 & 44 & 4.4 & -0.2 & 0.04 & 10 & 6.46 & 195 & 5.5 & -0.09 & 0.03 \\
\hline 3 & 5.7 & 50 & 3.3 & -0.25 & 0.04 & 15 & 6.5 & 280 & 4.2 & -0.16 & 0.05 \\
\hline 4 & 5.78 & 59 & 2.1 & -0.34 & 0.04 & 20 & 6.61 & 417 & 3 & -0.28 & 0.08 \\
\hline \multirow[t]{3}{*}{5} & 6.01 & 65 & 0.9 & -0.44 & 0.03 & 25 & 6.68 & 565 & 2 & -0.32 & 0.09 \\
\hline & & & & & & 30 & 6.82 & 825 & 1.4 & -0.37 & 0.06 \\
\hline & & & & & & 40 & 6.92 & 1195 & 0.3 & -0.46 & 0.1 \\
\hline $\begin{array}{l}\text { Sulfide } \\
\text { mM }\end{array}$ & $\begin{array}{c}\text { Final } \\
\text { pH }\end{array}$ & $\begin{array}{c}\text { Alkalinity as } \\
\mathrm{CaCO}_{3} \\
\left(\mathrm{mg} \mathrm{L}^{-1}\right)\end{array}$ & $\begin{array}{c}\text { Zn (mM) } \\
\text { Unreacted } \\
\text { Solution }\end{array}$ & $\begin{array}{c}\delta^{66} \mathrm{Zn} \\
\text { Unreacted } \\
\text { Solution }\end{array}$ & $2 \sigma(\%)$ & $\begin{array}{l}\text { Ferrihydrite } \\
\text { grams } L^{-1}\end{array}$ & $\begin{array}{c}\text { Sampling } \\
\text { (Hours) }\end{array}$ & $\begin{array}{l}\text { Zn (mM) } \\
\text { Unreacted } \\
\text { Solution }\end{array}$ & Final pH & $\begin{array}{c}\delta^{66} \mathrm{Zn} \\
\text { Unreacted } \\
\text { Solution }\end{array}$ & $2 \sigma(\%)$ \\
\hline 0.5 & 3.87 & ND & 7.5 & 0.07 & 0.04 & 2 & 0 & 75.6 & 7.2 & -0.14 & 0.04 \\
\hline 1 & 3.84 & ND & 7 & 0.07 & 0.01 & 2 & 0.25 & 69.8 & 7.2 & & \\
\hline 1.5 & 3.8 & ND & 6.5 & 0.09 & 0.06 & 2 & 0.5 & 65.6 & 7.2 & & \\
\hline 2 & 3.75 & ND & 6.2 & 0.14 & 0.01 & 2 & 0.75 & 64.3 & 7.2 & -0.16 & 0.04 \\
\hline 2.5 & 3.72 & 3 & 5.6 & 0.12 & 0.02 & 2 & 1 & 62.4 & 7.2 & & \\
\hline 3 & 3.69 & 6 & 5.2 & 0.14 & 0.03 & 2 & 3 & 51.9 & 7.2 & -0.2 & 0.06 \\
\hline 4 & 3.72 & 10 & 4.3 & 0.2 & 0.03 & 2 & 6 & 41.2 & 7.2 & -0.2 & 0.04 \\
\hline 5 & 3.83 & 13 & 3.4 & 0.27 & 0.03 & 2 & 9 & 35.8 & 7.2 & & \\
\hline 6 & 3.96 & 16 & 2.5 & 0.34 & 0.06 & 2 & 12 & 33.7 & 7.2 & -0.2 & 0.09 \\
\hline 7 & 7.15 & 33 & 1.5 & 0.41 & 0.06 & 2 & 14 & 32.2 & 7.2 & & \\
\hline 8 & 10.79 & 120 & 0.6 & 0.5 & 0 & 2 & 16 & 30.1 & 7.2 & -0.14 & 0.08 \\
\hline 9 & 11.23 & 197 & 0 & 0.55 & 0.05 & 2 & 18 & 26.9 & 7.2 & & \\
\hline \multirow[t]{3}{*}{10} & 11.45 & 296 & 0 & 0.76 & 0.05 & 2 & 20 & 20.8 & 7.2 & -0.19 & 0.01 \\
\hline & & & & & & 2 & 22 & 17.5 & 7.2 & & \\
\hline & & & & & & 2 & 24 & 8.2 & 7.2 & -0.21 & 0.05 \\
\hline
\end{tabular}




\section{References}

(1) Antelo, J.; Arce, F.; Fiol, S. Arsenate and phosphate adsorption on ferrihydrite nanoparticles. Synergetic interaction with calcium ions. Chem. Geol. 2015, 410, 53-62.

(2) Toby, B. H.; Von Dreele, R. B. GSAS-II: The genesis of a modern open-source all purpose crystallography software package. J. Appl. Crystallogr. 2013, 46, 544-549.

(3) Carta, D.; Casula, M. F.; Corrias, A.; Falqui, A.; Navarra, G.; Pinna, G. Structural and magnetic characterization of synthetic ferrihydrite nanoparticles. Mater. Chem. Phys. 2009, 113, 349-355.

\section{Acknowledgements}

The ferrihydrite sample for SRPD was analyzed at the Canadian Light Source during the NSERC TERRECREATE training program. The Canadian Light Source is supported by the Natural Sciences and Engineering Research Council of Canada, the National Research Council Canada, the Canadian Institutes of Health Research, the Province of Saskatchewan, Western Economic Diversification Canada, and the University of Saskatchewan. 